\title{
Forms of Employment of Highly Qualified Industry Professionals: The Impact of Labor Precarity on Intellectual Capital
}

\author{
Nadezhda N. Pokrovskaia \\ ${ }^{1}$ Department of Public Relations and Advertising \\ Herzen State Pedagogical University of Russia \\ ${ }^{2}$ Department of Advertising and Public Relations \\ Peter the Great Saint-Petersburg Polytechnic University \\ St. Petersburg, Russia \\ 1nnp@herzen.spb.ru, ${ }^{2} n n p @$ spbstu.ru
}

\author{
Natalia V. Burova ${ }^{3}$, Tatiana M. Konoplyannik ${ }^{4}$ \\ ${ }^{3}$ Department of Statistics and Econometrics \\ ${ }^{4}$ Department of Audit and Internal Control \\ St. Petersburg State University of Economics \\ St. Petersburg, Russia \\ ${ }^{3}$ nbourova@unecon.ru, ${ }^{4}$ anica80@mail.ru
}

\begin{abstract}
The development of the labor market and increased mobility of human resources allowed companies to move to a wider application of flexible management methods. The proliferation of new forms of employment has led to both positive results related to the expansion of opportunities for individual self-realization and the growth of independence and responsibility for personal, professional and socio-institutional growth, as well as to the negative consequences, especially precarization. Unsustainable employment, instability of income and of the sphere of activity, precariousness of employment as a form of structuring time and as a source of satisfying needs reflect the negative aspects of precarization, which today directly affect the sphere of education. Investing in human capital, primarily in the formation of an individual, is based on the longterm reasoning, and the unpredictability of return on investment (ROI) casts doubt on the formation of highly qualified personnel, especially in the field of changing high-tech industries with rapid innovative growth. The spread of partial employment, freelance, projects' work, the implementation of point orders under onetime contracts in the field of highly qualified industrial personnel increases the risk of loss of interest of the country's population in the formation of skills and knowledge, especially in engineering and technical fields with high requirements for cognitive practices, which is threat to the growth of intellectual capital of industrial enterprises, the region and the country as a whole.
\end{abstract}

Keywords - self-employment; precarization; employment; highqualified specialists; intellectual capital; industry

\section{INTRODUCTION}

The emergence of new forms of employment is reflected in the economic, managerial and social sciences in the form of expanding the terminology of models (gignomics, gift economics, we economy, etc.) and regulatory and political processes (participatory management, precarization of labor, etc.). The expansion of terminology reflects the multidimensional nature of the changes that occur in society during the rapid development of technology.

The production technologies are changing and approaches

The research was carried out with the financial support of the Russian Foundation for Basic Research, research project No. 16-29-12965 / 18. to management methods are evaluating with the use of labor and natural resources, accounting and goal-setting. E.g., if in the XX century industrial production relied on high-qualified workers, today complex routine operations are successfully carried out by robots [1], and the competence of personnel is embodied in the adjustment, reconfiguration, repair and rapid modernization of equipment.

The need to rethink the forms of employment of highly qualified specialists [2] is caused by both a rapid update of technologies and economic models of attracting the human resources [3], the professional experts to implement new kind of working activity, primarily associated with the development of intellectual capital of a company, industry, region or country.

\section{PRECARITY OF SKILLED LABOR AS A THREAT TO THE GROWTH OF INTELLECTUAL CAPITAL}

New forms of employment, on the one hand, meet the interests of citizens and the values of individual freedom, private human rights to make an independent choice of working conditions, time and place of work, the subject of efforts, projects and tasks, which will subsequently become part of the portfolio and resume.

On the other hand, the differentiation of employees and their removal from organizational business processes, the abolition or weakening of social protection and integration into the team, the fragmentation of labor lead to de-qualification of a person outside the socio-professional community and sociopsychological de-adaptation, which causes negative consequences for human potential of a company or a region, for the physical health and intellectual capital.

\section{A. Evolution of forms of satisfying industry's human resource requirements}

Mass industrial production with long payback periods for fixed assets, sophisticated and expensive machinery equipment, and rare technological modernization required constantly employed labor resources for efficient operation. The relation between the costs of material resources and human labor was in 
favor of the "materialized" labor in the machines and buildings. The physical objects were requiring the constant knowledge of the specific particular needs of equipment, the adaptation of a new worker could produce not only the additional costs but the catastrophic damage due to stop of production.

Long-term and perpetual labor relations were beneficial for the business until the innovative change of technology was fast enough to allow the change of busy human resources, since to train "old" personnel was comparable in cost to the adaptation and corporate socialization of new personnel.

At the same time, over-exploitation of the workforce led to a rather rapid depletion of the region's labor resources, which led employers to reduce working hours, improve working conditions, introduce social protection and develop investment in human resources. With the increasing complexity of engineering and technical work, enterprises were forced to provide not only the physical presence of the employees, but also stimulate their intellectual contribution, introduce programs to satisfy the social needs of employees and various forms of compensation management.

The development of the service sector as a third sector of the economy has led to a decrease in the importance of providing permanent workers in industry. As a result, full-time work for the entire working day regulated by law has become less suitable for the needs of employers than non-standardized work, including part-time work and the conclusion of contracts for specific work, free lance or short-term employment.

\section{B. The effects of employment precariousness in industry}

Part-time work and work under short-term or one-time employment and service contracts removes the employee from a number of state protection components: paying vacation pay and various benefits, reducing the length of service for a pension (e.g., when concluding a 10-month contract instead of a year, the length of service is reduced by $1 / 6$ part), a decrease or lack of support during a period of temporary disability, etc. The reduction or lack of social protection of precarious workers is complemented by increased stress and the diseases they cause, the poorer health reduces the quality of the physical human capital of the region and the country and increase the charge on the medical services and regional healthcare system.

Uncertainty in terms of obtaining a stable income leads to a decrease in the profitability of investing in education, which reduces the willingness of young people and their families to invest resources, primarily a time resource, in the intellectual capital of individuals [4].

A reduction in investment in intellectual capital and stress at work worsen health capital. This leads to the fact that parttime employment, beneficial for the employer, provided that the employee's full-time labor contribution is paid in part, becomes less profitable if the employee decides to give partial commitment instead of the full contribution to the labor, in terms of volume of work, and, what is even worse, a simultaneous decrease in the quality of labor. E.g., job sharing ("partial work" shared between several employees for a part of the rate with alternate presence at work [5]) has the opposite effect for the employer: a business expects to receive, e.g., a quarter of the volume of work while maintaining its quality, paying a quarter of the salary fee, but receives a quarter of the amount of work with quality reduced.

While in the service sector, a decrease in quality may be less noticeable, since the quality of a service in most cases is perceived simultaneously with the process of providing a service and its effect is preserved only in rare sectors (for example, finance), then in the industry there is an increase in rejects or insufficiently well conceived out engineering and technical solutions that affect the subsequent stages of product consumption - for example, if the CNC machine is not made well enough, the buyer of the machine will receive low quality products, and will not return for the purchase, will be looking for another manufacturer [6].

Reducing the competitiveness of industrial enterprises in the local and global markets due to insufficient staff involvement is a key problem of precarity of labor for business, which leads to the intention of manufacturing enterprises to hire employees at the full-time contracts, to increase their loyalty, and to invite freelancers only for such one-time jobs [7] that do not concern commercial and technological confidentiality.

\section{Intellectual capital of the self-employed}

While freelance is quite widely developed in the creative industries (marketing, art, etc.), highly qualified experts in industrial sectors, as a rule, represent a key resource for enterprise competitiveness, and employers strive to keep them as the key value added factor in the enterprise.

At the same time, sometimes highly qualified specialists themselves, having expert competence and a wide range of knowledge, prefer the precarious type of work on their own terms, which is due to follow their personal preferences and to maintain their right to use their personal intellectual capital at their own discretion [8]. The economic interest in the monopoly over the zone of uncertainty of an expert with unique knowledge and competence has led to the spread of the practice of inviting highly qualified specialists to design work with self-planning of tasks and even goal-setting, which is reflected in the status of self-employed.

Self-employment, in this case, is the form of using intellectual capital that is beneficial for the most highly qualified expert, since it is associated, along with low social security, with low payments to the State budget - instead of $13 \%$ of personal income tax and $30 \%$ of social contributions that the company pays for the employee, the self-employed person pays 4 or $6 \%$ (depending on whether the customer is an individual or legal entity) from the payment of their labor. These rates apply if the self-employed person receives less than the maximum of 2.4 million rubles per year.

The project use of an independent self-employed specialist, who is looking on his own for projects to take part and orders to carry out, who can work simultaneously for several organizations, allows the employer to access the unique intellectual capital of the self-employed, but at the same time raises the question of maintaining company loyalty and confidential data [9] of the organization. 


\section{FREEDOM OF CHOICE AND AGILE EMPLOYMENT AS VALUE}

Modernization and post-modernization of society [10] and the growth of basic needs satisfaction have formed a scale of values in which the most powerful motives are freedom of selfrealization and an innovative type of behavior, mobility and flexibility. Independence and willingness to bear responsibility for themselves and their decisions, which are characteristic not only for labor, but for entrepreneurial behavior, are the most important competence that forms secondary and higher education. Industry receives graduates who prefer to plan their time and set goals, determine the place and schedule of work.

\section{A. Flexible employment as a measure of employment}

Surveys of students completing graduate courses in the spring of 2019 (the total number of respondents was $N=181$ ) showed that masters of engineering and technology are less interested in the new forms of employment than the masters at social, humanitarian and economic areas. The composition of the respondents included 68 undergraduates in engineering and technical areas of study, including IT and physics, 113 - ethical and humanitarian (cultural studies, philosophy), social, economic, managerial areas (including advertising, sociology, etc.). The survey showed the following results (Table 1):

TABLE I. EMPLOYMENT FORM AS A CRITERION FOR THE CHOICE OF JOB BY THE MASTER STUDENTS

\begin{tabular}{|l|c|c|}
\hline \multirow{2}{*}{$\begin{array}{c}\text { Prefer to find a job after } \\
\text { university as... }\end{array}$} & \multicolumn{2}{|c|}{ Graduate students } \\
\cline { 2 - 3 } & $\begin{array}{c}\text { Humanitarian and } \\
\text { social areas }\end{array}$ & Engineering \\
\hline Full-time staff member & $43.4 \%$ & $85.3 \%$ \\
\hline Part-time staff member & $42.5 \%$ & $5.9 \%$ \\
\hline Freelancer & $23.9 \%$ & $17.6 \%$ \\
\hline will develop my business & $1.8 \%$ & $1.5 \%$ \\
\hline I do not know yet & $13.3 \%$ & $1.5 \%$ \\
\hline
\end{tabular}

Compiled by the authors

Significant differences were found in the number of options chosen - graduate students in engineering areas in the majority chose only 1 option from the proposed list $(11.8 \%$ of respondents chose 2 options), while among the humanitarian. social and economic and management areas, almost a quarter of respondents $(24.8 \%)$ noted 2 options. $13.3 \%$ of students in social and humanitarian areas did not decide on the choice yet.

Although the vast majority of graduate students completing engineering specialties $(85.3 \%)$ will choose the standard form of employment (full-time), but $17.6 \%$ ( 8 persons) indicated the possibility of working in freelance, with only 1 undergraduate indicating both these options, the remaining 7 chose freelance in conjunction with part-time or their company.

The perception of oneself in the structure of the labor market as an employee reflects the removal of undergraduates from their type of economic behavior (labor, project, contract or business) (Table 2), with the exception of entrepreneurs:
TABLE II. SELF-IDENTIFICATION OF QUALIFIED SPECIALISTS IN THE STRUCTURE OF THE EONOMIC BEHAVIOUR

\begin{tabular}{|c|c|c|}
\hline \multirow{2}{*}{$\begin{array}{c}\text { What do they plan to } \\
\text { become in the labor } \\
\text { market... }\end{array}$} & \multicolumn{2}{|c|}{ Graduate students } \\
\hline & $\begin{array}{c}\text { Humanitarian and } \\
\text { social areas }\end{array}$ & Engineering \\
\hline Employee & $69.9 \%$ & $54.4 \%$ \\
\hline Project Manager & $18.6 \%$ & $38.2 \%$ \\
\hline Self-employed & $9.7 \%$ & $5.9 \%$ \\
\hline Entrepreneur & $1.8 \%$ & $1.5 \%$ \\
\hline
\end{tabular}

Only 3 undergraduates who have chosen the development of their own company exactly indicated their role in the economic system (entrepreneur).

Thus, only $54.4 \%$ of graduates of engineering and technical master education believe that they will be employees (more than $90 \%$ of them indicated that they plan to become full-time or part-time full-time staff members of enterprises, see Table 1).

A significant part of those who chose their future freelance work chose the role of a project manager (like almost a quarter of those who plan to become a full-time employee): $38.2 \%$ of graduate students in engineering and technology, while at the same time, among social and humanitarian ones only $18.6 \%$ of respondents think so, and even fewer $(9.7 \%)$ plan to be selfemployed (although $23.9 \%$ of graduates in these areas were going to work on freelance).

The noted confusion in the self-identification of future high-qualified specialists completing graduate studies reflects an understanding of the danger of precarity of work in the minds of undergraduates, in this regard, even if the respondents look at the prospect of freelance with interest, they are not ready to take responsibility for the fullness of the work. Selfemployment is considered not as an attractive form of reducing the tax burden, but primarily as an unstable, unreliable and unsustainable form of employment that does not guarantee satisfaction of needs and return on investment [11].

The results of the analysis allow us to put forward a number of hypotheses that need to be clarified in the further research:

- Freelance is considered by master students as a form of additional earnings, and not the main form of employment, since it does not allow a specialist who has recently graduated from a university to receive a return on money and time invested in education quickly enough to cover costs

- graduates of social and humanitarian areas are more willing to work on third-party orders, but prefer to take less responsibility on themselves [12] than graduates of engineering and technical magistracy (applying for fulltime positions of employees, they perceive themselves as project managers rather than employees);

- self-employment is perceived as a precarious form of return on investing in intellectual capital and enjoys cautious interest of citizens. Digitalization of the economy increases the transparency of the labor market [13], which is likely to lead to an increase in the 
predictability of return on investment and, accordingly, an increase in interest in self-employment;

- Enterprises are expanding the involvement of experts, highly qualified specialists in new forms of employment with caution, since they perform functional roles crucial for the innovative growth of enterprises. In this regard, the differences between the masters of engineering and social sciences and humanities are associated not only with the personal characteristics of students, but also with job expectations.

The issues of obtaining a higher education of the second level (master's degree) are quite clearly associated in the students' minds with investing money and time resources in intellectual capital, which should bring income in an acceptable time frame and target volume, otherwise, undergraduates are not even ready to enter the master's budget programs (free of payment for them), to avoid losing two years [14].

If the macroeconomic problem of intellectual migration ("brain drain") requires regulatory measures on the part of the state [15], then the microeconomic issues of maintaining confidential information within the enterprise, maximizing employee involvement in business processes and the loyalty of highly qualified personnel need managerial solutions that allow managers "to tie" the employee to the enterprise in order to ensure a monopoly on intellectual capital.

\section{CONCLUSION}

The influence of labor precarity on the growth or degradation of intellectual capital is manifested in a reduction in mass investment in education, and at the same time, in the growth of the interest of unique highly qualified experts in fixing a monopoly on the individual's intellectual capital through self-employment and freelance.

\section{REFERENCES}

[1] I.A. Brusakova, "About problems of management of knowledge of the digital enterprise in fuzzy topological space," in Proc. of 2017 XX IEEE int. conference on Soft Computing And Measurements (SCM). N.Y.: IEEE Explore, 2017, pp. 792-795.

[2] N.N. Pokrovskaia, V.A. Spivak, and S.O. Snisarenko, "Developing Global Qualification-Competencies Ledger on Blockchain Platform," in XVII Russian Scientific and Practical Conference on Planning and Teaching Engineering Staff for the Industrial and Economic Complex of the Region (PTES) / Ed. S. Shaposhnikov. St-Petersburg: LETI-IEEE, 2018, pp. 209-212.
[3] I.A. Brusakova and R.E. Shepelev, "Innovations in the technique and economy for the digital enterprise," in IEEE 5th Forum Strategic Partnership of Universities and Enterprises of Hi-Tech Branches, Science. Education. Innovations. N.Y.: IEEE Explore, 2016, Vol. 5, pp. 27-29.

[4] F. Ülgen, "Schumpeterian innovations, financial innovations and instability: An institutional perspective," in J. of Economics and Finance, Asociación Cuadernos de Economía, 2015, vol. 38(106), pp. 46-53.

[5] N.A. Orlova, "Non-standard forms of employment and changes in human capital: analysis of the unskilled labor migration to Russia," in Monitoring of Public Opinion: Economic and Social Changes, 2017, No1, pp. 156-170.

[6] M.Yu. Ababkova and N.N. Pokrovskaia, "The growth of small business intellectual capital due to the spread of cheap robotics," in Systems analysis in engineering control: Proc. of the XXIII Int. conference. St.Petersburg: Publishing House Polytechnic Press, 2019, pp. 347-353.

[7] G. Standing, "Why zero-hours contracts remind me of the horrors of 1990s Russia," in The Guardian, 9 April 2013.

[8] M.A. Petrov, N.N. Pokrovskaia, and M.A. Gridneva, "Diagnostics of Professional Competencies and Motivation of the Engineer in the Knowledge Economy," 3rd Int. Conf. on Human Factors in Complex Technical Systems and Environments (ERGO). St-Petersburg: LETI, 2018, pp. 28-31.

[9] D.V. Golohvastov, N.N. Pokrovskaia, and S.O. Snisarenko, "Institutional Confidence and Economic Intelligence for the Performance at Macro and Micro Networks," in Proc. of The 4th International Conference on Management, Leadership and Governance ICMLG 2016 Host. Reading, UK: Academic Conferences and Publishing International Limited, 2016, pp. 255-263.

[10] Y.A. Margulyan and N.N. Pokrovskaia, "Social regulation mechanisms in the post-modern changing world," in Social processes regulation in the context of economics, law and management. LIII Int. Research and Practice Conference (London, 2013 June 06-11). London: International Academy of Science and Higher Education, 2013, pp. 59-61.

[11] F. Ülgen, "Financialization and Vested Interests: Self-Regulation vs. Financial Stability as a Public Good," in J. of Economic Issues, 2017 Vol. 51, issue 2, pp. 332-340. doi.org/10.1080/00213624.2017.1320512.

[12] M.Yu. Ababkova, D.A. Fedorov, V.L. Leontieva, and N.N. Pokrovskaia, "Semantics In E-Communication For Managing Innovation Resistance Within The Agile Approach," in the European Proc. of Social \& Behavioural Sciences EpSBS, 2018, Vol. LI, pp.1832-1842.

[13] F. Wei and N.N. Pokrovskaia, "The economic miracle of Celtic Tiger and post-crisis global regulative transformation for transparency," in Irland lessong: economy, society, culture, E.V. Beloglazova Ed. StPetersburg: State Unversity of Economics, 2015, pp. 15-25.

[14] G. Roth, "The Overproduction of Intelligence. The Reshaping of Social Classes in the United States," in The Brooklyn Rail, October 5th, 2015.

[15] L. Cappelli, R. Guglielmetti, G. Mattia, R. Merli, and F.M. Renzi, "Peer evaluation to develop benchmarking in the public sector," in Benchmarking: An International Journal, 2011, Vol. 18 No. 4, pp. 490 509. https://doi.org/10.1108/14635771111147605 